\title{
A EVANGELIZAÇÃO DOS "BÁRBAROS DA FLORESTA": D. JOSÉ AFONSO E A CRISTIANIZAÇÃO DOS ÍNDIOS NA DIOCESE DO PARÁ (1844-1857)
}

\author{
Allan Azevedo Andrade
}

Resumo: Apesar de olhar para os indígenas como selvagens, já que não se encaixavam dentro dos ditames da civilização cristã, o bispo do Pará, D. José Afonso, achava imprescindível ensiná-los o caminho da salvação católica. O escopo do presente artigo é analisar como o bispo se desdobrou para participar da evangelização dos índios, a partir do prisma da ortodoxia católica ultramontana, em sua diocese durante os anos de 1844 a 1857, esbarrando nos limites impostos pelo poder civil, mas buscando driblar isso com certa habilidade para não fugir de seu fito. Para isso, foi imprescindível o uso de documentos contendo discursos da Igreja e do Estado - jornais, livros, relatórios de presidente da província -, extraindo elementos que possibilitaram perceber as medidas de D. José com os índios e como ele lidava com estes.

Palavras-chave: D. José. Índios. Amazônia.

\section{THE EVANGELIZATION OF THE "FOREST BARBARIANS": D. JOSÉ AFONSO AND THE CHRISTIANIZATION OF THE INDIANS IN THE DIOCESE OF PARÁ (1844-1857)}

\begin{abstract}
Despite looking at the natives as savages, since they did not fit within the dictates of Christian civilization, the bishop of Pará, D. José Afonso, thought it was essential to teach them the path of Catholic salvation. The scope of this article is to analyze how the bishop, from his activities in his diocese between 1844 and 1857; and under the perspective of ultramontan Catholic orthodoxy, unfolded to participate in the evangelization of the Indigenous, meeting with the limits imposed by the civil powers, but seeking to circumvallate these restrictions through certain ability to not run away from his aim. For this purpose, it was essential to use documents containing discourses of the Church and the State - newspapers, books, reports of the president of the province - to extract the elements that made it possible to understand D. José's measures to the indigenous and how he dealt with them.
\end{abstract}

Keywords: D. José. Indigenous. Amazon.

\section{L'ÉVANGÉLISATION DES «BARBARIENS FORESTIERS»: D. JOSÉ AFONSO ET LA CHRÉTIANISATION DES INDIENS DANS LE DIOCÈSE DE PARÁ (1844-1857)}

Résumé: En dépit de considérer les indigènes comme des sauvages, car ils ne cadraient pas avec les exigences de la civilisation chrétienne, l'évêque du Pará, D. José Afonso, jugeait essentiel de leur enseigner la voie du salut catholique. Le but de cet article est d'analyser comment l'évêque s'est déployé pour participer à l'évangélisation des Indiens, du point de vue de l'orthodoxie catholique ultramontaine, dans son diocèse au cours des années 1844 à 1857, se heurtant aux limites imposées par le pouvoir civil, mais cherchant à contourner cela. avec une certaine capacité à ne pas fuir son objectif. Pour cela, il était essentiel d'utiliser des documents contenant des discours de l'Église et de l'État - journaux, livres, rapports du président de la province - pour extraire les éléments qui ont permis de comprendre les mesures de D. José avec les Indiens et comment il les a traitées.

Mots-clés: D. José. Indiens. Amazon.

\footnotetext{
${ }^{1}$ Doutorando pelo Programa de Pós-graduação em História Social da Amazônia (UFPA), mestre em História Social da Amazônia (2017). Professor da Secretaria Estadual de Educação.
}

Revista Escritas do Tempo - v. 1, n. 3, nov/2019-fev/2020 - p. 159-176 


\section{LA EVANGELIZACIÓN DE LOS "BÁRBAROS FORESTALES": D. JOSÉ AFONSO Y LA CRISTIANIZACIÓN DE LOS INDIOS EN LA DIÓCESIS DE PARÁ (1844-1857)}

Resumen: Apesar de considerar a los nativos como salvajes, ya que no encajaban dentro de los dictados de la civilización cristiana, el obispo de Pará, D. José Afonso, consideró esencial enseñarles el camino de la salvación católica. El alcance de este artículo es analizar cómo se desarrolló el obispo para participar en la evangelización de los indios, desde la perspectiva de la ortodoxia católica ultramontana, en su diócesis durante los años 1844 a 1857, tropezando con los límites impuestos por el poder civil, pero tratando de eludir esto. con cierta habilidad para no escapar de su objetivo. Para esto, era esencial utilizar documentos que contengan discursos de la Iglesia y el Estado (periódicos, libros, informes del presidente de la provincia) para extraer los elementos que permitieron comprender las medidas de D. José con los indios y cómo los manejó.

Palabras clave: D. José. Indios. Amazon.

\section{Introdução}

Pensar a evangelização indígena na Amazônia é compreender um espaço de assimilações e resistências criado por clérigos vinculado à ortodoxia romana, que visava mudar a formação religiosa a partir de uma submissão à autoridade papal. Além de buscar padrões de comportamento e ação entre o bispo do Pará e outros bispos do Brasil de orientação ultramontana, é importante também perceber as atitudes episcopais na Amazônia, motivadas pela realidade social, política e cultural da região, moldando o governo espiritual do prelado diocesano.

Antes de avançar no debate, vale frisar a conceituação de Ultramontanismo que tanto D. José Afonso se debruçou para aplicar. O Ultramontanismo é um conjunto de medidas teórico-práticas alicerçadas na condenação a modernidade em seu conjunto (sociedade, política, economia, cultura), tendo a medievalidade como referência, conquanto pautasse muita de suas ações no Concílio de Trento; centralização das atitudes da Igreja em Roma, reforçando a infabilidade papal, sobretudo após o estabelecimento dessa diretriz como dogma após o Concilio do Vaticano I, em 1870; valorização do episcopado e o reforço do magistério, retomando o Tomismo, considerado pela Igreja uma filosofia fundamental para o cristão (MANOEL, 2004, p. 45). No Brasil, esse movimento ganhou força em meados do século XIX, sendo D. José Afonso o pioneiro da campanha ultramontana no Pará.

Apesar da concisa definição de Ivan Manoel apontando aqueles que defendiam a ortodoxia romana e se opunham às políticas liberal e regalista - difundidas após a Revolução Francesa -, como ultramontanos, entendo que estes não configuram um grupo homogêneo, portanto, é necessário ter cuidado para distinguir tal conceito, 
considerando injunções, peculiaridades, e espaço/tempo da reforma ultramontana no Brasil e na Europa. Sendo assim, como diz Gustavo de Souza Oliveira (2015) em seu estudo comparativo do catolicismo ultramontano em Portugal e no Brasil, o Ultramontanismo não é fixo ou padronizado, mas um espaço conflituoso de ideias, perspectivas e práticas, embora, é claro, apresente preceitos em comum.

Dessa forma, além de estudar a campanha ultramontana como um "transplante" da Europa para a América, também é de igual importância, ou até maior, analisar o Ultramontanismo e as interferências que sofre do ambiente político e cultural. Portanto, segundo Gustavo Oliveira (2015) a reforma ultramontana é um espaço de "assimilações e resistências criado por clérigos vinculado à ortodoxia romana, que tinham como objetivos mudar a formação religiosa a partir de uma submissão à autoridade papal. Não se trata de um grupo coeso, mas de um processo de luta constante" (OLIVEIRA, 2015. p. 15).

A partir dessa premissa, o presente artigo visa estudar as intervenções do bispo ultramontano D. José Afonso de Moraes Torres junto aos indígenas na Amazônia enquanto esteve à frente da diocese do Pará $^{2}$ (1844-1857), analisando como seu múnus pastoral percebia os índios e buscava estratégias para salvação destes. Reconheço que nem sempre as ações de D. José Afonso, referente à salvação dos índios, podem ser encaixadas no repertório ultramontano, mas considero que sua cultura católicoconservadora foi parte integrante de seu episcopado na diocese no Pará, e mesmo que indiretamente, refletiu na forma de pensar os índios da região.

Nascido no Rio de Janeiro, em 1805, José Afonso de Moraes Torres foi educado pelos lazaristas na Congregação da Missão em Caraça - um dos centros de referência no que tange à formação de religiosos portadores da cultura ultramontana -, apartado, portanto, da tradição da formação sacerdotal brasileira reputada como a responsável pela formação deficiente dos padres nos negócios eclesiásticos e pouco interessados nestas. Depois de ordenado sacerdote em Mariana em 1829, voltou ao estabelecimento para ocupar o cargo de professor de filosofia e retórica, sendo nomeado em 1834 como superior do Colégio de Congonhas do Campo (também gerido pelos Lazaristas), ficando até 1838 , quando renunciou à condição de clérigo regular, tornando-se sacerdote secular

\footnotetext{
2 Tendo como sede a cidade de Belém, a diocese do Pará compreendia aproximadamente a toda atual Amazônia, abrangendo uma área de $4.000 .000 \mathrm{Km}^{2}$, até que fora fracionada com a criação da diocese do Amazonas no ano de $\underline{1892}$ pelo papa Leão XIII.
} 
e dirigindo-se para o Rio de Janeiro a fim de assumir a função de vigário colado da Freguesia do Engenho Velho.

Por indicação do governo imperial, o papa Gregório XVI nomeou o então pároco à condição de bispo da diocese do Pará em 1844, chegando à Belém em 7 de julho do mesmo ano. Preocupado com a aplicação das orientações oriundas da Santa Sé, o bispo D. José Afonso dedicou atenção aos sacramentos entre os fiéis e à formação de padres. Isso pode ser detectado na instituição de seminários ao longo de sua diocese. Mesmo com a dificuldade das grandes distâncias entre uma localidade e outra na diocese do Pará, o bispo resolveu eleger alguns núcleos para executar essa campanha religiosa. As cidades de Manaus (Comarca e Vigária geral do alto Amazonas), Óbidos (Comarca localizada no médio Amazonas) e Cametá (cidade nas margens do Tocantins paraense, principal frente de interiorização da ocupação e desbravamento do território) foram comtempladas com essa distinção.

Para desenvolver o estudo em tela, foi utilizada documentação proveniente de relatórios de presidente da província, Atas da Assembleia Legislativa Provincial, periódicos e livros da época. Essas fontes, em sua maioria, produzidas por autoridades civis e religiosas, mostram a visão do governo imperial e da Igreja sobre índios, contudo, ainda que entremeado de discursos oficiais do Estado e Igreja, e considerando as declarações contidas em periódicos e livros dessa época, é possível extrair dos documentos as pistas para entender a atuação de D. José Afonso junto aos indígenas na Amazônia, fazendo uso da involuntariedade dos testemunhos contidos nos documentos, tal como aponta Carlo Ginzburg (2007, p. 10 e 11) $)^{3}$, para entender a tentativa do prelado diocesano de controlar, disciplinar e normatizar a conduta e a cultura indígena na Amazônia.

\section{José Afonso e os indígenas na Amazônia}

De acordo com Manuela Carneiro da Cunha (2002), no século XIX prosperou a noção de que certas sociedades estariam atrasadas no percurso da linha evolutiva histórica. Os povos indígenas foram associados a essa condição retrógrada, e, segundo a teoria ocidental, estavam imersos em uma eterna infância. Essa concepção esteve

\footnotetext{
${ }^{3}$ A partir dos rastros deixados pelo tempo, Carlo Ginzburg se vale dos depoimentos involuntários para sua investigação, ao perseguir os fragmentos deixados pelo passado a fim de tentar reconstruir o quebracabeça da história ou mesmo criar possibilidades explicativas. Nesse sentido, ele faz valer os discursos incontrolados dentro da documentação, buscando extrair vestígios do passado de fontes que não tinham o interesse de serem deixadas para a posteridade. Consultar: GINZBURG, Carlo. $O$ fio e os rastros. Verdadeiro, falso, fictício. São Paulo: Companhia das Letras: 2007, p. 10-11.
} 
presente no discurso sobre o indígena na Amazônia oitocentista, tanto que, em relatório de Jerônimo Francisco Coelho (presidente da província do Pará) de 1848, são usados termos "almas ignorantes" e "selvagens" para rotular os povos nativos das Américas (COELHO, 1848. p. 1010).

Já no relatório apresentado à Assembleia Legislativa em 1862, Francisco Carlos de Araújo Brusque (presidente da província do Pará) diz que os núcleos de população indígena "reúnem o triste aspecto do homem no limiar da civilização" (BRUSQUE, 1862. p. 12). Esses são alguns exemplos de como a concepção de atraso e estado de barbárie recobria a visão europeia sobre os povos indígenas.

Importante destacar aqui a ideia de civilização, tão propalada no século XIX. Segundo o estudo de Robson Gomes Filho (2018), o termo civilização tem variado em seu uso e significado em diversas épocas. No entanto, a ideia de civilização está relacionada a descrição do nível técnico, urbanístico, político a reflexões sobre o modo como um dado povo se relaciona com seus próprios costumes, cultura e religião. Apesar dessa variedade, o cerne da ideia de civilização pode ser identificado a partir da construção da imagem do "outro". Ou seja, é a ideia que o ocidente tem de si mesmo, em que o dito civilizado está dentro de um padrão que indica, em termos gerais, uma fronteira entre aquilo que se julga avançado e evoluído (no qual o ser civilizado é parte integrante), distanciando-se de seu suposto passado primitivo e bárbaro:

Este 'orgulho que a sociedade europeia tem de si própria, de sua autoimagem de superioridade diante de um mundo que domina e que faz sentir-se superior', expresso pela ideia de civilização - ou Kultur, para as sociedades de língua alemã - tornou-se, especialmente, a partir do século 18, um modo homogeneizador de vencimento da barbárie por meio da padronização dos comportamentos e do autocontrole da violência e dos próprios instintos face à necessidade de cortesia, de etiqueta e de requinte (GOMES FILHO, 2018. p. 182).

Nesse sentido, o Brasil, em larga medida, herda essa referência civilizatória, no qual o padrão europeu de comportamento deve ser seguido, enquanto aqueles que não seguem tais ditames, são alocados em um patamar inferior na escala evolutiva da sociedade. Não por acaso, os índios eram vistos como bárbaros pelos europeus ou por brasileiros que partilhavam desta visão europeia, afinal, nem de longe o gentio se portava dentro do repertório da civilização.

A ideia do governo imperial era promover a civilização na Amazônia, como modo de pacificar a província. Dentro do projeto civilizatório do governo imperial, os indígenas adquiriam importância particular, principalmente na Amazônia, um dos locais

Revista Escritas do Tempo - v. 1, n. 3, nov/2019-fev/2020 - p. 159-176 
de maior presença destes. Na década de 1840 houve crescente interesse do poder público pela situação dos índios no Brasil, e um exemplo disso foi o decreto de $\mathrm{n}^{\circ} 285$ de 21 de junho de 1843 em que o governo autorizou a vinda de missionários capuchinhos da Itália para distribui-los em missões pelas províncias, enquanto que em junho de 1844 , por meio do decreto $\mathrm{n}^{\circ} 373$, foram fixadas as regras para a distribuição dos missionários pelas províncias (FRAGOSO, 1992, p. 296).

A política indigenista imperial na Amazônia se desenvolveu em meio aos resquícios do conflito da Cabanagem (1835 a 1840) ${ }^{4}$. Terminada a guerra cabana, o desafio era reconstruir o Grão-Pará, reorganizar a economia, bem como o tecido sóciopolítico-religioso e manter o controle sobre a população, visando evitar novos conflitos na província (HENRIQUE, 2017).

Por isso, enquanto D. José Afonso esteve à frente da diocese do Pará, entrou em vigor o decreto governamental número 426 de 24 de julho de 1845, que objetivava a reorganização das atividades de pacificação dos indígenas. Com essa nova organização, a diretoria dos índios passou a contar com diretores civis e, em menor número, com missionários católicos (MACIEL, 2014, p. 118).

Segundo Marcio Couto Henrique (2007), diferente dos séculos anteriores, em que as missões religiosas possuíam certa autonomia, já que as ordens formaram uma base econômica capaz de permitir essa liberdade, a catequese indígena no século XIX estava crucialmente dependente do governo civil na medida em que este ficou responsável pelo emprego e distribuição dos missionários, além de fornecer os recursos financeiros.

Assim, a atividade missionária passou a configurar-se como uma "rede de tutelas" que atravessava as relações entre Igreja, governo imperial e indígenas, uma vez que o Imperador era quem nomeava o Diretor Geral de Índios (que teria graduação de Brigadeiro) de cada província, e o presidente da província, e por sua vez, nomeava um Diretor Parcial (com graduação de Tenente-Coronel) para cada aldeia. Logo, esse

\footnotetext{
${ }^{4}$ De acordo com Magda Ricci (2007), a guerra cabana, ocorrida no Pará, explodiu em 1835 e se arrastou até 1840 , deixou mais de 30 mil mortos e uma população local que só voltou a crescer significativamente em 1860. "Este movimento matou mestiços, índios e africanos pobres ou escravizados, mas também dizimou boa parte da elite da Amazônia. O principal alvo dos cabanos eram os brancos, especialmente os portugueses mais abastados. Nascida em Belém do Pará, a revolução cabana avançou pelos rios amazônicos e pelo mar Atlântico, atingindo os quatro cantos de uma ampla região. Chegou até as fronteiras do Brasil central e ainda se aproximou do litoral norte e nordeste. Gerou distúrbios internacionais na América caribenha, intensificando um importante tráfico de ideias e de pessoas". RICCI, Magda. Cabanagem, cidadania e identidade revolucionária: o problema do patriotismo na Amazônia entre 1835 e 1840. Tempo, Niterói, v. 11, n. 22, p. 5-30, 2007.
} 
decreto concedia praticamente controle absoluto do Estado sobre os indígenas e os missionários. Desta feita, “a retórica da 'civilização' indica certo tom de secularização da política indigenista iniciada pelo Marquês de Pombal” (HENRIQUE, 2007).

Ainda que o manto da supraidentidade católica ${ }^{5}$ recobrisse a cristandade na Amazônia, o estado em que encontravam os indígenas da região não era satisfatório, haja vista eles não partilharem dos preceitos do catolicismo ortodoxo, ou sequer conhecer a cultura católica. Isso causou preocupação, inclusive, entre autoridades civis. Não sem razão, o presidente da Província do Pará em 1838, Soares Andrea, atribuiu à falta de religião um dos motivos para a situação caótica que o Norte havia chegado durante o contexto do movimento cabano:

(...) mas he sem duvida precizo tratar com muita attenção tudo quanto diz respeito á Religião; he precizo que Vós Senhores penseis com reflexão nas desgraças porque passou esta Provincia, e que reconheçaes que muitos Sacerdotes foraõ envolvidos entre os seus autores por hum modo que lhes não faz honra: o que para o Povo rude tem o effeito de desacreditar a Religião. He pois indispensavel melhorar tudo quanto respeita á admissão, e a Instrução desta Classe de Indivíduos, para que possamos hum dia ter Pastores dignos dos altos fins a que são destinados (Relatório de presidente da Província do Pará, 1838, p. 12).

Nos Relatórios dos Presidentes da Província do Pará e Amazonas - entre os anos de 1844 a 1858 -, a seção destinada à catequese indígena mostra o desempenho dos clérigos embrenhados no sertão Amazônico em busca da salvação das almas dos gentis em concorrência com a brutalidade da floresta. Os governantes redatores dos relatórios enfatizam a indispensabilidade do processo civilizatório como modelador de cidadania através da instrução religiosa, sendo este o primeiro aprendizado a introduzir o índio na sociedade nacional. Para isso, o poder civil esteve disposto a manter a obtenção de fundos para os padres vocacionados ao trabalho das missões dos índios aldeados, tal qual foi o caso dos capuchinhos nesta época.

Nesse cenário, em 1844, o Imperador D. Pedro II pede ao bispo D. José Afonso Torres que chame "à civilização as diferentes tribos indígenas, que habitavam suas matas, e não desfrutar as delícias de Belém” (TORRES apud AZZI, 1982), ficando

\footnotetext{
${ }^{5}$ Fernando Neves (2015), apoiado no estudo de Evandro Faustino (1991), entende que a "supraidentidade católica abriga diferentes modos de 'ser igreja', popular, ilustrado, tradicional sob hegemonia do catolicismo diocesano à testa da hierarquia" (NEVES, 2015. p. 22). Ainda que dentro da noção de supraidentidade católica comporte outras formas de experimentar o catolicismo, tais como aquelas formas de experimentar a religião que não são vistas com bons olhos pela Igreja oficial - como é o caso do catolicismo popular, ou ilustrado -, de forma geral, a hierarquia católica entende ser estas experiências católicas contornáveis solucionáveis a partir um melhor esclarecimento da doutrina, com ações da campanha ultramontana.
}

Revista Escritas do Tempo - v. 1, n. 3, nov/2019-fev/2020 - p. 159-176 
evidente o quanto a autoridade imperial via como problema a falta de civilização indígena em meio ao contexto do pós-guerra cabana. A Igreja acreditava estar conduzindo as populações indígenas à civilidade, porquanto eram considerados "bárbaros da floresta". Por conseguinte, sob o prisma católico de D. José, o índio era visto como uma categoria inferior, a qual a Igreja tinha como dever resgatar.

Assim, tal como o governo imperial, D. José Afonso também vislumbrava a civilização indígena, no entanto, o projeto do bispo não partilhava do princípio secularizante da catequese e civilização dos índios, adotado pelo Estado, na medida em que seu intuito era bafejar o máximo possível com os preceitos católicos ortodoxos o contato com o indígena, inclusive aplicando os sacramentos da Igreja quando visitou as aldeias, tal como mostra o registro do século XIX, publicado posteriormente em jornais do século XX:

A Aldeia de santa Cruz tem para mais de 500 Mundurucus aldeiados e algum
tanto civilizados; uma pequena Igreja que tinham construídos estava por acabar-
se, mas com minha chegada fizeram esforços para concluí-las, e pude benzê-la,
assim como uma grande cruz que se arvorou em frente do templo. Batizei eu
mesmo 13 crianças com o fim de animá-los e tinham um prazer de chamarem
depois seu compadre. Mostraram-se tão indispostos a serem governados por
diretores que me disseram que apenas o diretor aí se estabelecesse retiravam
para o mato [...] (TORRES, José Afonso de Moraes. Voz de Nazaré, Belém, 23
Jul. 1978. p. 3).

No século XVIII e XIX, os índios Mundurucu foram diversas vezes chamados pelos portugueses para combaterem os índios Mura, conhecidos pela extremada barbárie e hostilidade. Em troca desse apoio bélico, os Mundurucu tiravam proveitos obtendo vantagens materiais. Durante a Cabanagem, os Mundurucu já habituados às alianças com os colonos na região, tiveram o papel de perseguidores dos rebeldes cabanos, principalmente, na região que ficaria conhecida na época por "Mundurucânia". De outro modo, houve Mundurucu que, por terem sido recrutados pelos Corpos de Trabalhadores e forçados ao trabalho compulsório em áreas distantes de suas povoações, juntaram-se aos cabanos e acabaram sendo perseguidos juntamente com os tapuios (SULIMAN, 2013). Portanto, o contexto conflituoso, juntamente com as marcas da guerra cabana estavam muito presentes entre esses índios. Foi em meio a esse cenário conturbado que o bispo D. José Afonso foi ao encontro dos Mundurucu aldeados.

A despeito dos prováveis exageros feitos nesse relato do bispo, a descrição sobre o contato com os índios Mundurucu é bem rica para perceber a expectativa de D. José em levar aos indígenas os valores católicos, narrando tanto a construção da igreja 
quanto sua atitude em aplicar o sacramento do batismo nas crianças da aldeia. Ainda sobre o documento destacado, o panorama de insucesso do projeto de catequese do governo imperial, com os diretores acusados de explorar desmedidamente o trabalho indígena, é determinante para entender o relato de aversão dos índios aos diretores e os casos de abandono dos aldeamentos.

Para o bispo diocesano, a presença de sacerdotes naquele local seria mais frutífera do que uma autoridade civil, por isso, questiona a qualidade dos diretores definidos pelo governo:

(...) e quantas aldeias entregues ao abandono sem missionários? Seria para desejar que alguns sacerdotes de outras províncias e mesmo da Europa quisessem vir prestar seus serviços à religião e salvação de tantas almas, que se perdem por faltas de pastores, e compadecendo-se de tantos infiéis embrenhados pelos nossos matos se enchessem de zelo pela propagação da fé e viessem chamá-los ao centro da Igreja de J Cristo; vejo-me atormentado com repetidas requisições dos povos pedindo-me padres sem poder satisfazê-los, e é pena os mesmos índios fazendo todas as deligencias para os obter sem consegui-lo. Um tuxaua (principal da nação) disse a um dos diretores de uma aldeia que viria à capital com bastante farinha e guaraná para "comprar-me um padre", tal era o desejo de possuí-lo. Não faltam disposições, faltam diretores que as saibam encaminhar, e duplicado seria o fruto de meus trabalhos, se em cada aldeia que visito, pudesse deixar um missionário (TORRES, José Afonso de Moraes. Voz de Nazaré, Belém, 21 mai. 1978. p. 3).

Conquanto não tenha sido possível confirmar a veracidade desse pedido do "tuxaua" descrito por D. José, vale aqui o registro do relato do bispo para captar sua insatisfação quanto à escassez de padres para o trabalho missionário nas aldeias. $\mathrm{O}$ prelado do Pará sentiu o incômodo de não poder ajudar como queria as aldeias indígenas com os sacerdotes, até porque, não eram tão numerosos assim os clérigos na diocese do Pará (ANDRADE, 2017), e os que haviam não cumpriam à risca as prescrições definidas pela Igreja, por isso, D. José Afonso mostrava-se ansioso pela vinda de missionários de outras províncias e até mesmo vindos da Europa, para ajudarem na empreitada da salvação das almas desses nativos.

Essa experiência no interior da diocese, aliada às informações sobre os índios da região, proporcionou maior sensibilidade do bispo à causa indígena. Por isso, quando foi deputado provincial em $1846^{6}$, D. José Afonso apresenta um artigo aditivo ao

\footnotetext{
${ }^{6}$ D. José Afonso se dedica à política parlamentar pouco mais de um ano depois de sua entronização a frente da diocese quando ele foi eleito deputado da Assembleia Legislativa do Pará em 1845, sendo o segundo mais votado dentre os 28 eleitos. A vida religiosa de José Afonso de Moraes Torres é entremeada pelas atividades políticas, isso porque, embora a primeira sessão da Assembleia provincial tenha ocorrido no dia 20 de abril de 1846, por conta de sua segunda visita pastoral, o prelado do Pará toma posse do seu cargo político apenas em setembro do mesmo ano. Além disso, também foi eleito
} 
projeto de número 210 (que previa o melhor ordenamento da instrução pública por meio de um regulamento para o "Estabelecimento de Educandos do Pará", a fim de amparar as necessidades da educação dos órfãos e desvalidos) na Assembleia Legislativa do Pará, no intuito de criar uma escola de educandos em Santarém e outra na Barra do Rio Negro (Livro das Actas da Assembleia Legislativa Provincial do Pará, 01 de outubro de 1846). Malgrado não ser um estabelecimento exclusivamente religioso, a instituição de ensino era concebida por ser local de educação e difusão dos princípios civilizatórios, tendo a religião como alicerce desse intento, afinal, a educação também é um projeto religioso, que nesse caso, D. José pretendia estender até o interior da diocese, já que, na concepção religiosa, o verdadeiro saber é aquele que conduz a vontade divina.

Com a proposição da criação desses estabelecimentos em Santarém e Barra do Rio Negro, D. José Afonso pretendia contemplar com a educação os numerosos indígenas presentes naqueles locais e arredores. Nos relatos das visitas pastorais do bispo pelo interior do Pará é possível extrair de suas falas informações referentes a considerável quantidade de índios tanto em Santarém quanto em Barra do Rio Negro. Mesmo com o grande número de índios (especialmente os Mundurucu) que habitavam a região do Tapajós, D. José faz questão de afirmar, em carta pastoral de 16 de novembro de 1846, que, depois da capital, Santarém era "a primeira povoação da província".

Já Barra do Rio Negro era uma cidade de grande influência na região do AltoAmazonas, não por acaso, o prelado diocesano optou por propor para aquele lugar a casa de educandos. Tal foi sua preocupação com essa área que em 1848 o bispo fundou o seminário S. José em Barra do Rio Negro. Essas pistas induzem a perceber o grau de importância que o bispo deu para os referidos locais.

Sendo assim, uma forma de complementar o projeto civilizador era estender a educação até os referidos locais para que as crianças, inclusive as de origem indígena, fossem comtempladas, tal como diz o deputado provincial José Bernardo Santarém ao afirmar - durante as várias discursões sobre mencionado artigo aditivo - que os estabelecimentos nessas localidades irão "transformar a juventude indigena de que [...] abundão em cidadãos uteis, cujo o fim de certo não poderá preencher o estabelecimento dos educandos da Capital com aquella plenitude que ao Paiz convem" (Livro das Actas da Assembleia Legislativa Provincial do Pará, 02 de outubro de 1846).

deputado à Assembleia Geral pelo Amazonas em 1852, na expectativa de lograr recursos materiais capazes de atender as necessidades da Igreja (ANDRADE, 2017).

Revista Escritas do Tempo - v. 1, n. 3, nov/2019-fev/2020 - p. 159-176 
Em relação aos recursos destinados às missões indígenas, o presidente da província Jerônimo Coelho afirma que "são tão escassos recursos da renda provincial" que não estavam atendendo "às numerosas necessidades, [...] para manter tantas missoens, e fundar tantos aldeiamentos em todos os pontos, em que elles se fazem preciosos" (COELHO, 1848. p. 101). Por isso, mesmo com o decreto de 1845, que dava rigoroso poder sobre a organização da missão ao Estado, D. José Afonso buscou certo grau de autonomia para a Igreja na escolha e pagamento desses missionários, como consta no Relatório de Residente da província de 1848:

O Exm. ${ }^{\circ}$ Prelado Diocesano, officiando-me a este respeito em data de 28 de Agosto proximo passado, lembra a ideia de se pedirem Missionarios a Associação da Fé, concorrendo o Thesouro com alguma quantia para seus cofres, ou então criar-se aqui em uma casa de Lazaristas, à imitação do que se fez na Provincia de Minas, convidando-se 2 sacerdotes daquella Congregação, que viessem aqui criar um noviciado com o fim exclusivo de formar missionarios. (Relatório de Presidente da Província, 1848, p. 101.)

Devido à falta de documentação, não se sabe se o projeto do bispo de criar um estabelecimento lazarista saiu do papel - embora a probabilidade de não ter vingado seja grande -, mesmo assim é relevante ressaltar que, ao pensar em civilizar os índios, o horizonte D. José Afonso eram os Padres da Congregação da Missão São Vicente de Paulo (referências na difusão do Ultramontanismo), no qual estes iriam formar missionários moldados nos preceitos ultramontanos e levar o evangelho de Deus aos indígenas. Já seu plano de criar a "Associação da propagação da fé" se concretizou. Ao criar essa associação, D. José Afonso tinha como propósito "augumentar a Fé, e ajudar com suas esmolas os Missionarios destinados a catequese dos indigenas" (INSTRUCÇÕES. Treze de Maio, Belém, 11 Jun. 1845. p. 1).

Como se vê, o bispo não viu apenas o erário público como alternativa de recursos financeiros para a catequização, julgando ser necessária a criação de uma associação para sustentar os missionários:

Tendo já decorridos já um anno desde 29 junho de 1845 a esta parte, que pelo Apostolico zelo de sua Rvm. ${ }^{\text {os }}$ Parochos, a cujos cuidados está incumbido o promover esta importante Obra nas suas respectivas Parochias façaõ a competente entrada do producto dos annuaes, e d'outras esmollas, que tenhã̃ por ventura agenciado das pessoas já allistadas nesta Pia Associação (BASTOS, Luiz Barros de. AVISOS. Treze de Maio, Belém, 22 Ago. 1846. p. 3).

Não foi possível depreender o cotidiano dessa associação criada pelo bispo, e nem identificar se esta obteve significativo êxito, mas o que fica claro na documentação 
é a grande dedicação de D. José Afonso à questão dos índios, como fica expresso no Relatório de Presidente da Província de 1845 em que é reconhecida sua preocupação com os "selvagens", sendo destacado, até mesmo, o contato do prelado com o Papa Pio IX sobre o referido assunto:

Mas o Exm. ${ }^{\circ}$ Prelado Diocesano tem-se empenhado com maior zelo e desvelo em ocorrer a esta falta, solicitando informações sobre a classe de Religiosos mais próprios e dedicados a este serviço, e até escrevendo directamente ao Summo Pontifice a este respeito como vereis em parte da informação, a quem me tenho referido, e que novamente recommendo a vossa leitura, e atencção; e nutre bem fundadas esperanças de obter para o serviço das Missões os mais acreditados Missionarios (Relatório de Presidente da Província, 1845).

Não obtendo o sucesso desejado com as solicitações ao poder civil, D. José Afonso via como alternativa difundir o catolicismo conservador aos índios na ocasião das visitas pastorais que fazia pelas aldeias, como foi o caso de uma povoação indígena localizada em uma das margens do lago do Jurutí.

(...) Preguei aqui em frase acomodada ao auditório composto de índios ainda mal civilizados, e que pouco entendem da nossa língua, depois do que subiu ao púlpito o vigário geral, e lhes pregou na língua geral indígena. Crismei 300 e tantas pessoas, tive a ocasião de conversar com vários índios Mundurucus e significar-lhe o desejo que tinha de ver aldeados todos os seus companheiros, que ainda existiam nas brenhas. Fiz o que eu pude a este respeito com o dito vigário geral, e eles se mostraram dispostos a irem ao mato dar notícias da nossa viagem pelo Amazonas. Dia 30 - Partimos acompanhados de 46 canôas em que vinham os índios cantando os versos que costumamos ensinar ao povo em todas as freguesias, em que se cantam no fim do sermão. Seguiram-nos desde as 4 horas da tarde até alta hora da noite, quando se despediram de nós, voltando todos recompensados com rosários, verônicas e outros objetos de devoção que muito apreciam [...] (TORRES, José Afonso de Moraes. Voz de Nazaré, Belém, 25 Jun. 1978. p. 3)

Mais uma vez fica evidente a preocupação do bispo com os índios "mal civilizados", por isso, ele fez pregações, aplicou os sacramentos e presenteou-os com objetos católicos. Ademais, tentou, junto aos índios já aldeados, o convencimento daqueles que estavam nas matas vivendo sem os direcionamentos cristãos. D. José insiste, em seus escritos, em afirmar a boa vontade dos índios em receber a mensagem católica, quando sugere, por exemplo, no documento citado, que os índios receberam de bom grado rosários, verônicas e outros objetos de devoção que muito apreciavam. Provavelmente, os índios davam outros sentidos para aqueles símbolos católicos que haviam recebido, de qualquer forma, o que fica claro no documento é que, se na teoria os índios estavam sob a tutela do Estado, na prática, o bispo do Pará - que não deixava 
de ser um representante do poder civil, mas pendia muito mais para a esfera religiosa fez questão de tentar orientar os gentis nos trilhos do cristianismo.

É perceptível a maior facilidade de contato com os índios a partir do uso da "língua geral”, nesse sentido, toda essa preocupação de D. José Afonso com a catequese indígena o levou a voltar suas atenções para o estudo da referida língua, dedicando-se ao aprendizado dela:

Comecei a estudar aqui a língua indígena geral por que conheci a necessidade que tinha de falar, e para isso servi-me de alguns pequenos índios que sabiam o português [...]. Escrevi 1500 vocábulos, decorei-os e puz-me a compor frases; ao principio mal feitas eram objetos de riso para os pequenos, mas consegui poder confessar na língua na mesma freguesia de São Paulo e tive o prazer de ouvir confissões de pessoas que nunca se tinham confessado por não terem padres que entendessem sua língua (TORRES, José Afonso de Moraes. Voz de Nazaré, Belém, 08 Out. 1978. p. 3)

Desse modo, ele foi responsável - junto ao então ministro da Justiça Eusébio de Queiroz -, através de um decreto em 1851, pela criação da matéria que visava o aprendizado dessa língua dentro do Seminário Episcopal do Pará, tendo em vista a preparação do clero no intuito de facilitar a aproximação e catequização dos nativos. Isso fica explícito no prefácio do "Compendio de Lingua Brazilica" escrito pelo coronel reformado do exército Raymundo Correia de Faria que fora nomeado por D. José Afonso como sucessor de Manoel Justiniano de Seixas ao posto de lente da respectiva cadeira no Seminário:

Commovido o nosso exímio Prelado da necessidade que havia, de chamar ao gremio da Igreja essas hordas de selvagens, barbaras, ignorantes, embratecidas, extraviadas, e sobre tudo dignas de compaixão; espalhadas pelas nossas vastas e incultas florestas, sem conhecimento algum de Deos nem de nossas crenças; e sendo o meio mais apropriado o antigo methodo das Missões, julgou indispensavel, principalmente para aquelles candidatos que se propozerem ás Freguesias do interior, o conhecimento da Língua Geral, adoptada pelos Jesuitas, e por meio da qual tudo havião conseguido n'aquelles tempos (FARIA, F.R.C. de. Compendio da Lingua Brazilica. Pará, Typ. de Santos \& Filho, 1858).

Essa ação de criar a cadeira de língua indígena, e posteriormente, o referido dicionário, se deu após as muitas andanças pelo interior da diocese em visita pastoral e a dificuldade de se comunicar com os indígenas no trabalho de evangelização, expectando melhor oportunidade de transmissão do pensamento religioso, e recepção da fala dos índios, sem precisar de intermediários que filtrassem a informação. D. José havia principiado estudar a língua geral indígena, mas quando quis colocar em prática sentiu 
grande dificuldade, pois segundo ele, "a Arte e o dicionário por onde estudei não podiam já servir pelas alterações que a língua tinha sofrido com o tempo. É hoje inteiramente diversa da que se falava há anos atrás" (TORRES, José Afonso de Moraes. Voz de Nazaré, Belém, 16 jul. 1978). Daqui depreende-se o cuidado do bispo com a qualificação desse contato, buscando a melhor maneira de aprender e se atualizar na língua geral para buscar a evangelização dos indígenas bem como o repasse desse ensino dentro do seminário.

A influência de D. José Afonso, na condição de maior autoridade religiosa da diocese, lhe permitiu também procurar persuadir o poder público a levar a palavra de Deus aos aldeamentos, tal como correu com Herculano Ferreira Penna, presidente da recém-criada província do Amazonas, que atendeu às reflexões que lhe "fez S. Ex. ${ }^{a}$ R. ${ }^{\text {ma }}$ o Snr. Bispo Diocesano a respeito da creação de uma Capella Fillial da Missão do Andirá" (Relatório de Presidente da Província, 1853, p. 61). Essa atenção do bispo aos índios localizados nessa região já se dava desde 1847 quando ele visitou a "aldeia do Andirá", tal como é relatado no itinerário de sua visita pastoral:

Fomos recebidos em uma das casas de palha, de que se compoe a aldeia, e fomos obsequiados pelos indios da maneira que lhes foi possivel. Um dos principais com seu interprete, me veio falar em nome dos seus, pedindo um padre, e que lhes mandasse batizar as crianças. Satifez a sua vontade, prometendo-lhes dar a seu tempo um missionário, (já o tem) e mandei batizar 19 crianças por um dos religiosos que me acompanhavam, depois do que chamei os principais da nação e lhes disse que S. M. o Imperador era seu amigo e desejava que fossem cristão e bons vassalos, homens que vivessem sempre conosco em paz e que lhes prometia toda a proteção, e brindes de que precisassem, que fossem dizer isto mesmo aos que viviam nas matas, os chamassem para a aldeia e que logo que eles viessem lhes daria o Padre me pediam. Ficaram satisfeitos e prometeram de assim cumprir dizendo-me que estariam todos juntos se não praticassem com eles injustiças. Disse-lhes que a intenção do governo de S. M. Imperial não eram essas, mas sim fazer-lhes todo o bem, e que hoje já tinham um Inspetor para evitar essas opressões de que se queixavam. Tinham eles toda a razão (TORRES, José Afonso de Moraes. Voz de Nazaré, Belém, 20 ago. 1978. p. 3).

A mediação feita por D. José Afonso em nome do governo imperial para arregimentar cada vez mais índios da nação Maués para o aldeamento de Andirá expressa o cuidado no trato com este povo pelo receio acumulado devido aos antecedentes de conflitos nesse aldeamento. A ação do governo civil concorria com indivíduos interessados em utilizar a força de trabalho dos indíos para fins particulares, incultindo-lhes ensinamentos contrários à civilização, sendo assim, diante disso, o prelado do Pará vê a necessidade de reforçar a ideia de que o Imperador estava do lado 
dos indígenas, incentivando os já aldeados a convencer os outros que "viviam nas matas" a se juntarem a esse reduto de "civilização". Enquanto para os índios a presença de um padre poderia significar uma maior segurança contra possíveis abusos de autoridades civis nos aldeamentos, para o bispo D. José Afonso o desejo em ter um sacerdote na aldeia era entendido como uma oportunidade de converter e/ou reforçar nessa população, a doutrina cristã.

De acordo com Marcio Couto Henrique (2007), a experiência missionária na Amazônia oitocentista deve ser pensada levando-se em consideração variantes como, o “descrédito da atuação missionária, a diversidade de projetos de catequese, a necessidade de reorganização da mão-de-obra e os conflitos oriundos da relação entre brancos e índios" (HENRIQUE, 2007). Em meio a essa diversidade, D. José Afonso de Moraes Torres intentou civilizar os índios, compactuando com a proposta do Estado, até certa medida, pois pelo menos em tese, ele vislumbrou incorporar alguns traços do catolicismo oficial nessa catequização. Entretanto, se a atuação do bispo entre os indígenas não surtiu grande efeito - por não ter ajuda de muitos religiosos, não obstante houvesse a presença de capuchinhos na região, bem como as amarras que o governo civil imprimia sobre a atuação religiosa, principalmente por conta da falta de recursos vindos dos cofres públicos -, vale identificar sua preocupação com a civilização dos gentios, até porque na Amazônia, a recorrência do contato com esses povos era grande em várias de suas visitas pastorais.

Por isso, mesmo atendendo a um pedido do Imperador quanto à civilização dos índios, pode-se perceber que D. José busca levantar a bandeira da Igreja Católica nas várias aldeias em que visitou, principalmente, nas regiões do Baixo e Alto Amazonas. Além disso, embora contasse com o auxílio dos capuchinhos - ainda que em número escasso -, o bispo tinha a intenção de também contar com a ajuda do clero secular, a partir do momento em que estabelece o estudo da língua geral indígena para que os vocacionados da batina pudessem qualificar seu contato com indígena a fim de torna-los bons católicos.

\section{Conclusão}

Importante sublinhar que durante o pastorado de D. José Afonso (1844-1857), não existia ainda um Episcopado reunido como um corpo religioso e político a fim de proclamar os direitos da Igreja Católica no Brasil, isto é, ratificando a autoridade do 
catolicismo "sobre doutrina, liturgias e ritos, tanto quanto sobre concepção de mundo, organização social e quotidiano" (NEVES, 2015, p. 301).

Destarte, mesmo que houvesse diretrizes emanadas de Roma para a aplicação do catolicismo diocesano, não havia ainda um plano traçado no Brasil de como proceder para dar fôlego ao projeto ultramontano como houve nas décadas posteriores a partir da Pastoral Coletiva de 1890, que foi um documento dirigido ao clero e à cristandade, representando um ato político de demonstração de força e união do Episcopado para enfrentar ameaças da recém-instituída República (GOMES, 2009, p. 179). Para Fernando Neves (2015), a existência do Episcopado Nacional, já em fins do século XIX, significou o alargamento da esfera secular para comportar a Igreja na modernidade, sendo a própria Igreja modernizada em meio ao diálogo com as forças do século.

Assim sendo, na ausência do Episcopado Nacional, em meado do século XIX, os bispos das províncias do Império geriam suas dioceses segundo seu entendimento. Com D. José Afonso de Moraes Torres não foi diferente. Em virtude dessa falta de centralização do Episcopado, o prelado do Pará se sente à vontade para colocar em prática seu programa ultramontano da maneira que acha mais adequado, imiscuindo-se inclusive na política, sempre levando em conta as instruções pastorais provenientes da Santa Sé, mas deixando transparecer a capacidade criativa da Igreja, conformada na tradição. A partir dessa premissa, é justificável concluir que D. José Afonso considerou as especificidades do local, agindo de acordo com as necessidades do seu bispado, demonstrando ser um ultramontano apto para o tempo e espaço no qual exerce seu pastorado.

Seria exagero afirmar que D. José Afonso aplicou a campanha ultramontana entre índios na mesma medida que fez entre os fiéis e os clérigos. Porém, o entendimento de sua concepção católica serve para melhor compreensão das atitudes do bispo diante da evangelização dos indígenas, sua preocupação em levar a salvação às "almas ignorantes", em meio ao ensejo das amarras jurídicas estabelecidas pelo governo civil para submeter os religiosos à vontade do Estado, no qual D. José não se encaixava, ao mesmo tempo que não enfrentava acintosamente o governo, sendo cuidadoso e habilidoso no trânsito entre esfera civil e espiritual, visando a qualificação de sua missão pastoral. 


\section{Referências}

ANDRADE, Allan. Entre a Igreja e o Estado: atribuições e atribulações de um bispo ultramontano na Amazônia (1844-1857). Dissertação (Mestrado em História), Universidade Federal do Pará - UFPA, Belém, 2017.

AZZI, Riolando. "D. José Afonso de Moraes Torres, ex lazarista no bispado do Pará". Revista Convergência, p. 177-192, 1982.

CUNHA, Manuela Carneiro da. Política Indigenista No Século XIX. In: Maria Manuela Ligeti Carneiro da Cunha. (Org.). História dos Índios no Brasil. São Paulo: Cia. das Letras, 2002.

FARIA, Raymundo Correa de. Compendio da Lingua Brazilica. Pará, Typ. de Santos \& Filho, 1858.

FRAGOSO, Hugo. "A igreja e os índios (1875-1889)". In: HOORNAERT, Eduardo (Org.). História da Igreja no Brasil: ensaio de interpretação a partir de um povo segunda época. Tomo II/2. 4. Ed. Petrópolis: Vozes; 1992.

GOMES, Edgar da Silva. A Dança Dos Poderes: uma História Da Separação EstadoIgreja No Brasil. São Paulo: D'escrever: 2009.

GOMES FILHO, Robson Rodrigues. Os missionários redentoristas alemães e as expectativas de progresso e modernização em Goiás (Brasil, 1894-1930). Tese (Doutorado em História), Universidade Federal Fluminense, Rio de Janeiro, RJ 2018.

GINZBURG, Carlo. $O$ fio e os rastros. Verdadeiro, falso, fictício. São Paulo: Companhia das Letras: 2007.

HENRIQUE, Márcio Couto. Presente de branco: a perspectiva indígena dos brindes da civilização (Amazônia, século XIX). Revista Brasileira de História (impresso). v. 35, p. 195-216. 2017.

"Sem Vieira, nem Pombal: memória jesuítica e as missões religiosas na Amazônia do século XIX”. Asas da Palavra (UNAMA), v. 10, Belém, p. 209-233, 2007.

HENRIQUE, Márcio Couto. "Sobre a (in)visibilidade dos índios da Amazônia (século XIX)". In: Magda Maria de Oliveira Ricci; Maria de Nazaré Sarges. (Org.). Os oitocentos na Amazônia: política, trabalho e cultura. 1ed.Belém: Açaí; 2013.

JORNAL TREZE DE MAIO. Belém, 11 de junho de 1845. Fundação Tancredo Neves (Centur).

JORNAL TREZE DE MAIO. Belém, 22 de agosto de 1846. Fundação Tancredo Neves (Centur).

JORNAL VOZ DE NAZARÉ. Belém, 21 de maio de 1978. Cúria Metropolitana (Arquidiocese de Belém) 
JORNAL VOZ DE NAZARÉ. Belém, 25 de junho de 1978. Cúria Metropolitana (Arquidiocese de Belém)

JORNAL VOZ DE NAZARÉ. Belém, 16 de julho de 1978. Cúria Metropolitana (Arquidiocese de Belém)

JORNAL VOZ DE NAZARÉ. Belém, 23 de julho de 1978. Cúria Metropolitana (Arquidiocese de Belém)

JORNAL VOZ DE NAZARÉ. Belém, 08 de outubro de 1978. Cúria Metropolitana (Arquidiocese de Belém)

JORNAL VOZ DE NAZARÉ. Belém, 20 de agosto de 1978. Cúria Metropolitana (Arquidiocese de Belém)

LIVRO DAS ACTAS DA ASSEMBLEIA LEGISLATIVA PROVINCIAL DO PARÁ. Belém, 01 de outubro de 1846.

LIVRO DAS ACTAS DA ASSEMBLEIA LEGISLATIVA PROVINCIAL DO PARÁ. Belém, 02 de outubro de 1846.

MACIEL, Elisângela S. Igreja de Manaus, porção da Igreja Universal: a Diocese de Manaus vivenciando a romanização (1892-1926). 1. ed. Manaus: Editora Valer: 2014.

MANOEL, Ivan Aparecido. O pêndulo da História. Tempo e eternidade no pensamento Católico (1800-1960). Maringá: Eduem: 2004.

NEVES, Fernando Arthur de Freitas. Romualdo, José e Antônio: Bispos na Amazônia do oitocentos. 1. Ed. Belém: Editora da UFPA: 2015.

OLIVEIRA, G. S. Aspectos do ultramontanismo oitocentista: Antônio Ferreira Viçoso e a Congregação da Missão em Portugal e no Brasil (1811-1875). Tese (Doutorado em História), Universidade Estadual de Campinas, Campinas, SP, 2015.

RELATÓRIOS DOS PRESIDENTES DA PROVÍNCIA DO AMAZONAS (1851 a 1858). Disponíveis em: http://www.crl.edu/brazil.

RELATÓRIOS DOS PRESIDENTES DA PROVÍNCIA DO PARÁ (1844 a 1858). Disponíveis em: http://www.crl.edu/brazil.

RICCI, Magda. Cabanagem, cidadania e identidade revolucionária: o problema do patriotismo na Amazônia entre 1835 e 1840. Tempo, Niterói, vol.11, n.22, pp.5-30, 2007.

SULIMAN, Sara. "Os índios Munduruku e o zeloso capuchinho no rio Tapajós (Pará, 1848-1854)". In: XXVII Simpósio Nacional de História - ANPUH, 2013, Natal - RN. XXVII Simpósio Nacional de História - ANPUH - Conhecimento Histórico e Diálogo Social, 2013. (Anais Eletrônicos).

Artigo recebido em 8 de janeiro de 2020. Aprovado em 4 de fevereiro de 2020. 